\title{
交差点遅れを考虑した利用者均衡配分に関する研究“ A Study on User Equilibrium Assignment considering Intersection Delays ${ }^{*}$
}

\author{
内田 賢悦**, 岸 邦宏 ${ }^{* * *}$, 佐藤 馨一*** \\ By Ken-etsu UCHIDA, Kunihiro KISHI and Keiichi SATOH
}

\section{1. はじめに}

これまで交通量配分モデルの拡張は，Wardrop 均衡を そのままの形で解くことが可能なように定式化されてき た.たとえば動的モデル ${ }^{1)}$, 時間帯別均衡配分モデル ${ }^{2)}$, ファジィリンク所要時間を導入したモデル ${ }^{3)}$ などが挙げ られる。

一方，交通現象として信号交差点での自動車の挙動を 考えると, 右折車の交差点遅れが対向直進車の影響を受 けるように，一般にリンクコスト関数にはリンク間相互 干涉がある.また, 都市部における道路ネットワークで の交通現象を考えると, 交差点遅れが経路所要時間に占 める割合は無視できないほど大きい。したがって，こう した道路ネットワークでの交通量配分には，リンク間相 互干渉がある交差点遅れを表現したモデルが必要である.

こうしたリンク間干涉のある利用者均衡配分に関する 研究として, Meneguzzer ${ }^{4)} や$ Walting ${ }^{5)}$ 研究が挙げられ る.一般に，リンク間干渉のある利用者均衡配分には, 均衡解の唯一性, 収束性に問題があることが知られてい る.この問題点に対応するために，全てのリンクで収束 させるのではなく，95\%のリンクが収束したときに，近 似的均衡状態にあるとして計算を終了する方法が提案さ れている.その結果, 初期実行可能解に関わらず, 相応 な配分交通量が再現されることが報告されている。

信号交差点の影響を交通量配分にとりいれた

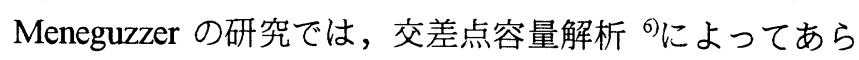
かじめ飽和交通流率を算定して, 交差点遅れを表現する 必要がある. しかし交差点遅れは, 飽和交通流率や交通 の到着分布における变動の影響を受ける功めそのの推 定にはこうした要因に対する調整プロセスが必要である。

こうした背景から，筆者らはメンバーシップ関数を用 いた交差点遅れ推計モデルを開発してきた ${ }^{8), 99}$. 同モデ ルにおける交差点遅れは, 平均交差点遅れを中心值とす る三角ファジィ数で表現されている.ファジィ交差点遅 れの右・左スプレッドを決定するパラメータ值は, 交差 点遅れを再現するために重要な要素であるため, 交差点 遅れを計測することにより算定した。

\footnotetext{
“キーワード 配分交通, ネットワーク交通流, 経路選択

“学生員 修(工) 北海道大学大学院工学研究科都市環境工学専攻

（札显市北区北 13 条西 8 丁目，Tel 011-706-6822，Fax 011-726-2296）

****正会貝 博(工) 北海道大学大学院工学研究科都市環境工学専攻

（札幌市北区北 13 条西 8 丁目, Tel 011-706-6216, Fax 011-726-2296)

*****フエロー 工博 北海道大学大学院工学研究科都市環境工学専攻

（札幌市北区北 13 条西 8 丁目，Tel 011-706-6209，Fax 011-726-2296）
}

本研究は, 同交差点遅れ推計モデルを利用者均衡配分 にとりいれた都市部における交通流解析法を提案するも のである。

\section{2. 交差点遅れ推計モテル}

\section{(1)推計方法}

信号交差点を自動車が通過するとき，所要時間からみ た通過の容易性は一般に, 流入交通量が増えるにつれて 低下し，さらに流入交通量が交差点交通容量を越えると その低下率は大きくなる。本研究では，この関係をリン ク間の交差点ノードで起こる通過性の低下によるものと 解釈し, 流入交通量が増えるにつれて通過性が低下する 関係を通過性指数によって表現する. 直進車, 左折車, 右折車の流入交通量(それぞれ $\left.q_{S}, q_{L}, q_{R}\right)$ を変数とする 通過性指数(それぞれ $\left.\mu_{S}, \mu_{L}, \mu_{R}\right)$ は, 直進, 左折, 右 折車線の交通容量(それぞれ $\left.C_{I}^{S}, C_{I}^{L}, C_{I}^{R}\right)$ を用いて表現 する. 通過性指数を式 1 と図 1 に示す.

$$
\begin{array}{ll}
\mu(q)=(k-1) \frac{q}{C_{I}}+1, & 0 \leq q \leq \mathrm{C}_{\mathrm{I}}, 0<k<1.0 \\
\mu(\mathrm{q})=\frac{\mathrm{k}}{1-\alpha} \frac{q}{C_{I}}+\frac{\alpha}{\alpha-1} k, & \mathrm{C}_{\mathrm{I}}<q \leq \alpha C_{I}, \alpha>1.0 \\
\mu(q)=0, & q>\alpha C_{\mathrm{I}}
\end{array}
$$

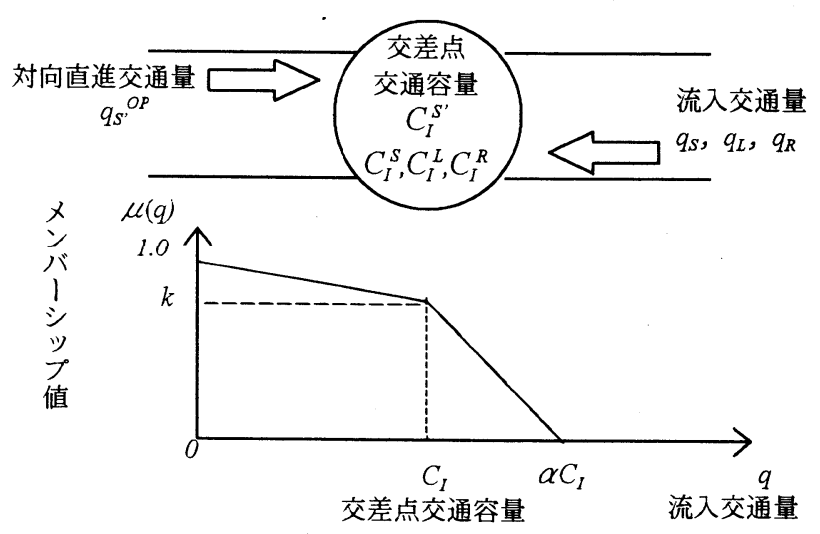

図 1. 交差点でのリンク間通過性指数

ここで交差点交通容量 $\left(C_{I}\right)$ は，飽和交通流率に青時間 比(e)を乗じた值である（式 2 ).

$$
C_{I}=S \cdot e
$$

$S$ は飽和交通流率であり, 直進, 左折, 右折車線それぞ れについて交差点形状などの確定的要因で算定した值と する。 
通過性指数 $(\mu)$ は信号交差点における通過のしやすさ であるため, 直進車と左折車の通過性指数は流入交通量 に依存し, 右折車の場合は, 流入交通量と対向直進交通 量 $\left(q^{O P}{ }^{\prime}\right)$ ) に依存すると仮定する。このとき, 直進車と 左折車の通過性指数をそれぞれ $\mu^{S}=\mu_{S}\left(q_{S}\right), \mu^{L}=\mu_{L}\left(q_{L}\right)$ で定義する. 右折車の通過性指数を対向直進車 $\left(q^{o p}{ }_{S}\right)$ を変 数とする通過性指数も考慮し， $\mu^{R}=\mu_{R}\left(q_{R}\right) \cdot \mu_{S}\left(q^{O P}{ }_{S}\right)$ で 定義する. $\mu_{S}\left(q_{S}\right), \mu_{L}\left(q_{L}\right), \mu_{R}\left(q_{R}\right)$ が等しい值をとると き, 式 3 が成り立つ.

$$
\begin{array}{lll}
\mu^{S}=\mu^{L}>\mu^{R} & \text { when } & q^{O P}{ }_{S^{\prime}}>0 \\
\mu^{S}=\mu^{L}=\mu^{R} & \text { when } \quad & q^{O P}{ }_{S^{\prime}}=0
\end{array}
$$

次に，推計の基本となる三角ファジィ数 $T\left(t_{R}, t_{C}, t_{L}\right)$ を 設定する（図 2).

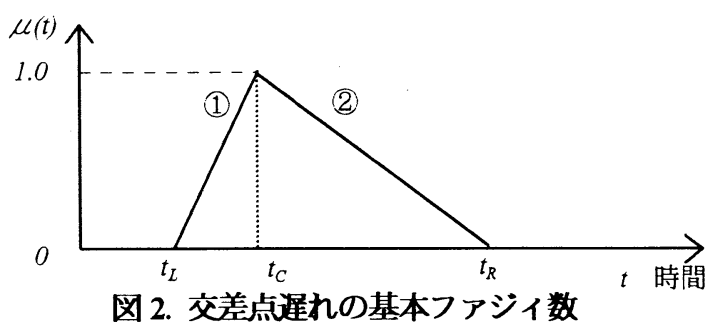

ここで $t_{C}$ は，三角ファジィ数の中心值であり，一様到着 での平均遅れ時間として式 4で表現する.

$$
t_{C}=\frac{c(1-e)^{2}}{2\left(1-e\left(q / C_{I}\right)\right)}
$$

$c$ は信号のサイクル時間である. $t_{R}, t_{L}$ はそれぞれ，三角 ファジィ数の右スプレッド, 左スプレッドである. 右ス プレッドは，パラメータ $\beta$ を交差点での進行方向（直進， 左折，右折）それぞれについて $\beta_{S} ， \beta_{L} ， \beta_{R}$ を用いて式 5 で表す。

$$
t_{R}=\beta \cdot t_{C} \quad \beta \geqq 1
$$

左スプレッドはパラメータ $\gamma$ を交差点での進行方向それ ぞれについて $\gamma_{S} ， \gamma_{L} ， \gamma_{R}$ を用いて式6で表す。

$$
t_{L}=\gamma \cdot t_{C} \quad 0<\gamma<1
$$

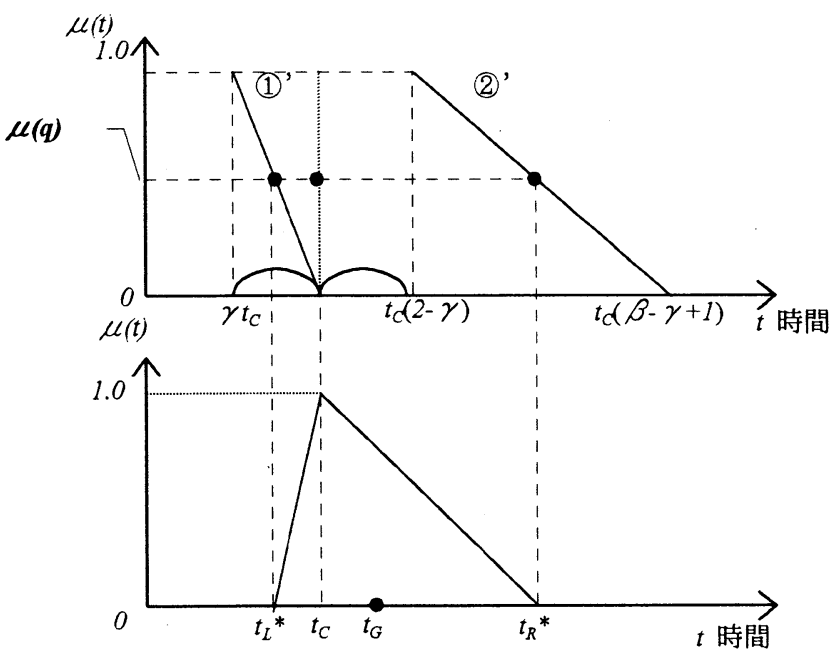

図3. 交差点遅九の推計
通過性指数が 1.0 のとき, 交差点遅れの中心值に対し て左右対称なファジィ交差点遅れとなり，通過性指数が 小さくなるにつれてファジィ交差点遅れの左スプレッド は中心值 $\left(t_{C}\right)$ に近い值をとり，右スプレッドは $t_{C}(2-\gamma)$ よ りも大きな值をとることを表現するため，以下に示す変 換を行う. 図 2 で中心值より左側の直線(1)を $\mu(t)=0.5$ の 軸で対称に折り返した直線(1) に変換し，さらに中心值 より右側の直線(2)を中心から左スプレッド間の時間を右 にシフトさせた直線(2)'に変換する (図 3 上)。こうし てできた直線と通過性指数が交わる時間をファジィ交差 点遅れの推計值 (中心值: $t_{C}$, 左スプレッド: $t_{L}$ *および右 スプレッド: $\left.t_{R}{ }^{*}\right)$ とする（式 7, 式 8 および図 3 下）.

$$
\begin{gathered}
t_{L}^{*}=t_{C}\{1-\mu(1-\gamma)\} \\
t_{R}{ }^{*}=t_{C}\{(1-\mu) \beta+1+\mu-\gamma\}
\end{gathered}
$$

ファジィ交差点遅れの代表值としては, 重心值 $\left(t_{G}\right)$ を用いることにする（式 9).

$$
\begin{aligned}
t_{G} & =\frac{1}{3}\left(t_{L} *+t_{C}+t_{R} *\right) \\
& =\frac{t_{C}}{3}\{-\mu(\beta-\gamma)+\beta-\gamma+3\}
\end{aligned}
$$

ファジィ数の代表值を重心值としたのは，三角ファジィ 数によって一意に決まること, 計算が容易でわかりやす いことが理由として挙げられる.本研究では 4.で交差点 遅れがファジィ数, リンクの所要時間がクリスプ数で表 現される最短経路を考える.このとき，それらの和とし ての経路所要時間は拡張原理によりファジィ数で表現す ることができる．その代表值としてもファジィ経路所要 時間の重心值をとりあげ，大小比較を行っている.

図3より，0< $\mu<1.0$ のとき式 10 が成立する.

$$
t_{L}^{*}<t_{C}<t_{G}<t_{R}^{*}
$$

直進車，左折車の場合， $\mu$ は流入交通量の関数，右折車 の場合は流入交通量と対向直進交通量の関数となる. 一 方, $t_{C}$ は流入交通量の関数となるため, 流入交通量の変 化により $\mu, t_{C}$ は変化する.このとき， $\mu$ の值が小さい ほど $t_{L}{ }^{*}, t_{R}{ }^{*}$ は大きな值をとり，その結果 $t_{G}$ は $t_{C}$ よりも大 きな值をとる.また， $t_{L}{ }^{*}$ は $t_{C}$ よりも小さいため, $t_{G}$ の值 を小さくする作用がある. 逆に $t_{R}^{*}$ は $t_{C}$ よりも大きいた め, $t_{G}$ の值を大きくする作用がある.

$\mu の$ 值が一定のときは， $t_{L}{ }^{*}$ はパラメータ $\gamma$ の関数とな り，式 7 における(1-y)の值が大きいほど，すなわちパ ラメータ $\gamma$ の值が小さいほど $t_{L}{ }^{*}$ は小さい值をとる．また $\mu の$ 值が一定のとき, 式 8 より $t_{R}^{*}$ は $\beta$ と $\gamma$ の関数となる が，人は図 2 における(2)の直線を右にシフトさせるもの なので, 主に式 8 における $\beta$ 值が大きいほど $t_{R}^{*}$ は大き い值をとる。

本推計法では, パラメータ とが信号が青現示のときに 自動車が到着するといった, 交差点遅れを小さくする要 因の影響を表していると解釈できる. パラメータ 
和交通流率や交通の到着の変動が交差点遅れにおよぼす 影響を表していると解釈できる。たとえば，右・左折車 混入率の増加といった要因である.

通過性指数はそれらの要因が交差点遅れにおよぼす影 響の度合いを決定するものである。 $t_{L}^{*}$ に関しては， $\mu か ゙$ rの影響の度合いを調整しており, 式 7 における

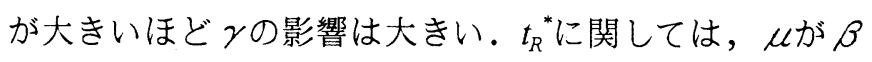
の影響の度合いを調整しており, 式 8 の(1きいほど，すなわち $\mu$ の值が小さいほど $\beta$ 影響は大き い.

たとえば，通過性指数が 1.0 のとき式 7 右辺の值は $\gamma t_{C}$ となり, 式 8 右辺の值は $2 t_{C}-\gamma t_{C}$ となるため, $t_{L}{ }^{*}$ に関し ては $\gamma$ の影響が最大となり， $t_{R}{ }^{*} に$ 関しては $\beta$ 影響はな くなる。このときのファジィ交差点遅れは，中心值に対 して左右対称なファジィ数となっており，その代表值と しての重心值は中心值と一致する．このとき，交差点遅 れを減少させる要因の影響は最大となり, 逆に交差点遅 れを増大させる要因の影響はないことを示している.

通過性指数が 0 に近づくと，パラメータ $\gamma$ の影響は小 さくなり，逆にパラメータ $\beta$ 影響は大きくなるのは， 交差点に流入する交通量が増えるにつれて（通過性指数 が小さくなるにつれて), 交差点遅れを減少させる要因 の影響は小さくなり, 逆に交差点遅れを増大させる要因 の影響は大きくなることを示している。

交差点遅れは, 飽和交通流率や交通の到着分布よって 変動する. 本モデルは，こうした要因による影響をパラ メータ $\beta$ とによって調整することで, ファジィ交差点 遅れの重心值が，中心值よりどれくらい大きな值をとる か決定するものである。

\section{(2)パラメータ值の設定法}

\section{(a)パラメータ $\beta, \gamma$ 設定}

ファジィ交差点遅れのスプレッドを決定するパラメー 夕值は, 交差点遅れの計測值によって定めることにする. ここでは, 通過性指数の設定值 $(k, \alpha)$ が決められている ものとして説明する.

交通状況が一定のもとで交差点遅れを計測し，交差点

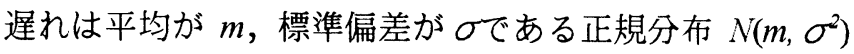
に従うと仮定する．同じ状況で推計されるファジィ交差 点遅れを $T\left(t_{R}{ }^{*}, t_{C}, t_{L}{ }^{*}\right)$ とする。このとき, $t_{R}{ }^{*}$ および $t_{L}{ }^{*}$ は 式11で表される。

$$
\begin{aligned}
& t_{L}{ }^{*}=f\left(t_{C}, \mu, \gamma\right) \\
& t_{R}{ }^{*}=g\left(t_{C}, \mu, \gamma, \beta\right)
\end{aligned}
$$

ここで $f, g$ は関数である. ファジィ交差点遅れの広が

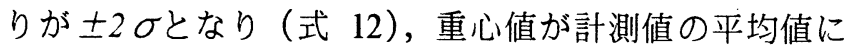
一致する（式 13）ことを仮定する。

$$
\begin{gathered}
t_{R}{ }^{*}-t_{L}{ }^{*}=4 \sigma \\
\left(t_{R}{ }^{*}+t_{C}+t_{L}{ }^{*}\right) 3=m
\end{gathered}
$$

$m ， \sigma は$ 交差点遅れ計測により得られる。交差点遅れの
計測により 1 時間当たりの交通量, 信号のサイクル長, 青時間比を求め, さらに交差点交通容量を車線数と青時 間比より算定することによって, 式(4)より $t_{C}$ は求められ る.また，通過性指数の設定值 $(k, \alpha)$ を決めておくと， 山は交差点交通容量と 1 時間当たりの交通量より求めら れる（図 1).したがって，式(12)と式(13)は $\beta$ とに関 する連立 1 次方程式となり，これを解くことにより $\beta$ ， $\gamma$ を算定できる（図 4 ).こうして求めたパラメー夕值 を用いることで，計測を行ったときの流入交通量に対応 する交差点遅れ関数の值は, 交差点遅れ計測值の平均值 と一致する。

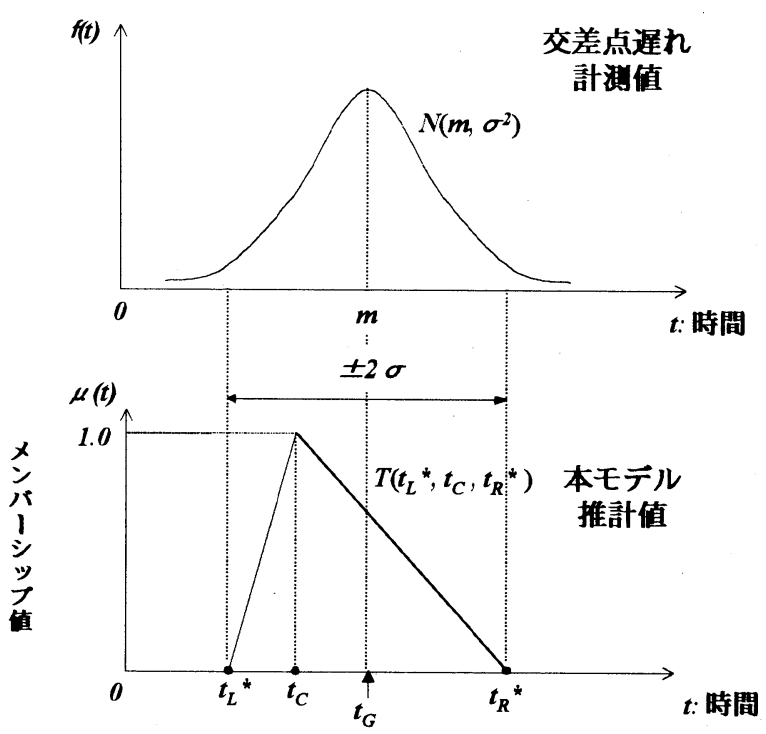

図 4. 交差点荤れ計测によるパラメー夕值の算定

\section{(b)通過性指数の設定値 $(k, \alpha)$}

ここでは，通過性指数を決定する設定值 $(k, \alpha)$ につい て考える。

通過性指数 $\mu$ が小さくなるほど $t_{L}{ }^{*}, t_{R}{ }^{*}$ 小゙大きな值を とり，その結果 $t_{G}$ が $t_{C}$ より大きな值をとることは 2.(1) で述べた。流入交通量が変化するとき, 飽和未満 $\left(q<C_{I}\right)$ では $t_{G}$ と $t_{C}$ の乘離幅は小さく, 過飽和 $\left(q \geqq C_{I}\right)$ での乘離幅

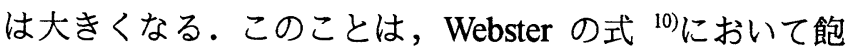
和未満での交差点遅れは $t_{C}$ との乘離幅が小さいことから わかる

仮に通過性指数の設定值 $k$ が決められたとすると, 過

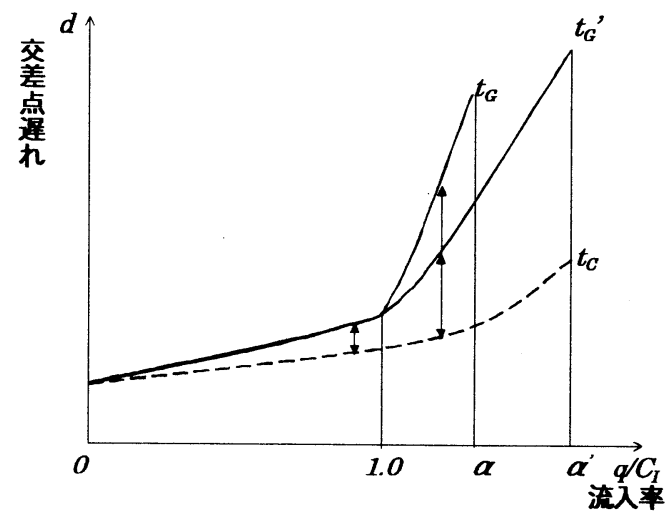

図 5. $\alpha$ の值による排蟭愊の変化 
飽和での $t_{G}$ と $t_{C}$ の乘離幅は, 通過性指数の設定値 $\alpha$ にも 依存する.すなわち 2 つの值 $(1.0<) \alpha<\alpha^{\prime}$ をとると, 流 入交通量が同一のとき， $\alpha$ の方が $t_{G}$ と $t_{C}$ の乘離幅は大き くなる(図 5)。

交差点遅れ計測は流入交通量が飽和未満の状態で行わ れたと仮定する.このとき, 適当な $k$ を決めるとパラメ 一夕值 $(\beta, \gamma)$ は推定される.これらのパラメータ值によ って流入交通量が過飽和における交差点遅れも適切に表 現されるためには， $k$ の值が 0.8 以上であることが必要 であり，このときのパラメータ值を $\left(\beta^{*}, \gamma^{*}\right)$ とする.こ れは， $k=0.7$ で推定されるパラメータ, 值 $\left(\beta^{\prime}, \gamma\right)$ では， $\alpha$ の設定值に関わらず流入交通量が過飽和での $t_{G}$ と $t_{C}$ の靟 離幅が小さくなってしまうためである.この主な原因は, パラメータ $\beta$ 'の值が $k=0.8$ 以上としたパラメータ $\beta^{*}$ の 值よりも小さくなるためである. また， $k<1.0$ であるこ とを考慮すると, $k$ は $0.8 \sim 0.9$ とするのが妥当である.

また $k$ の值が $0.8 \sim 0.9$ に設定されたとき， $\alpha$ の值が 1.1 〜 1.4 であると $t_{G}$ と $t_{C}$ の乘離幅が適切に表現される.こ れは， $\alpha$ の值が 1.5 以上であると $t_{G}$ と $t_{C}$ の乘離幅が小さ くなってしまうためである.また， $\alpha は$ 交差点遅れ遅れ の定義域でもあるため, 1.1 とすると交差点交通容量の 1.1 倍に相当する交通量しか信号交差点を通過できない。 ピーク時を考えると 1.2 倍以上の交通量があると考えら れるので， $\alpha に は 1.2 〜 1.4$ の值を設定するのが良い.

ここでの設定は，3.(2)で示す Akcelic の式，O.D モデ ル, Websterの式を参考にして行っている.

\section{3. パラメータ值の測定}

\section{(1)交差点遅れの計測}

ファジィ交差点遅れ推計に必要なパラメータ $(\beta, \gamma)$ を算定するために，乾燥路面における交差点遅れの計測 を行った。計測場所は，札幌市の代表的な交差点である 地下鉄東西線, 南郷 7 丁目駅前交差点であり, 1998 年 11 月 19日の 13:00〜 15:00に計測を行った。

計測方法は, 直進, 左折および右折の各車線ごとに交 差点の流入部と流出部に 1 台ずつ, 計 2 台のデジタルビ デオカメラを設置して撮影し, その通過時間の差を交差 点通過所要時間とした.さらに, 自動車の自由走行速度 を $50 \mathrm{~km} / \mathrm{h}$ (法定速度) として交差点遅れを算出した。

表 1. 交差点荤九の計測值（翰燥路面）

\begin{tabular}{|l|r|r|r|}
\hline & \multicolumn{1}{|c|}{ 直 進 } & \multicolumn{1}{|c|}{ 左 折 } & \multicolumn{1}{c|}{ 右 折 } \\
\hline デ一タ数 & 162 & 52 & 26 \\
\hline 平均 (秒) & 33.77 & 39.18 & 57.57 \\
\hline 標準偏差 & 28.90 & 21.98 & 29.18 \\
\hline 最大值 & 92.12 & 78.12 & 116.84 \\
\hline 最小值 & 8.12 & 11.12 & 18.84 \\
\hline 平均交差点遅れ & 30.10 & 24.00 & 21.90 \\
\hline 交通量 (台/時) & 641 & 195 & 90 \\
\hline 対向車 (台/時) & & & 641 \\
\hline
\end{tabular}

表 1 は交差点遅れの計測值とその統計量を示している. ここで平均交差点遅れとは, ファジィ交差点遅れの中心 值である. 平均交差点遅れの計算に必要な飽和交通流率 は, 直進については 2000 台/時とし, 左折および右折に ついては歩行者の影響を考慮して 1300 台時とした。

表 2 に交差点遅れの計測値より算定された, パラメー 夕值を示す。

\section{表 2. 交差点遅れのパラメー夕值（乾嬠路面）}

\begin{tabular}{|l|r|r|r|}
\hline & 直 進 & \multicolumn{1}{|c|}{ 左 折 } & \multicolumn{1}{c|}{ 右 折 } \\
\hline パラメータ $: \gamma$ & 0.01 & 0.09 & 0.76 \\
\hline パラメータ $: \beta$ & 4.84 & 53.50 & 53.73 \\
\hline
\end{tabular}

算定されたパラメータ值による交差点遅れ関数を図 6 に 示す.

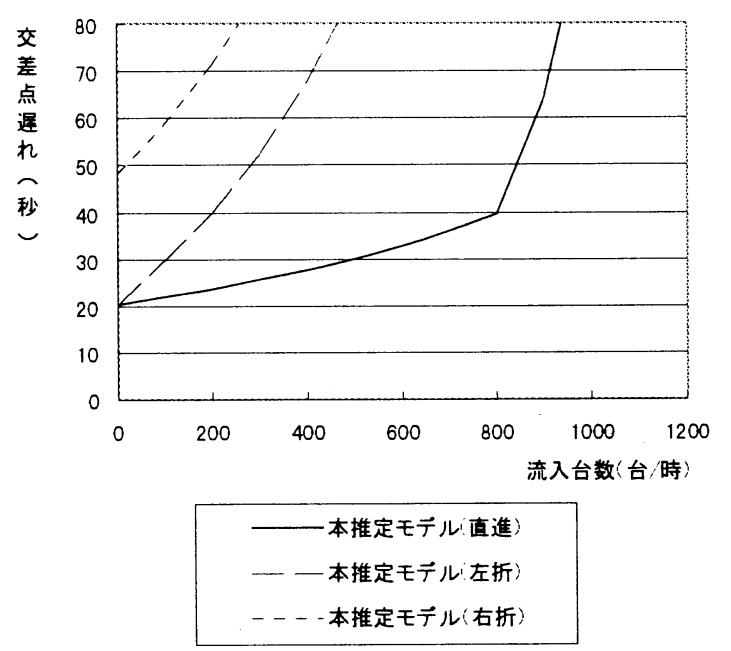

図6.パラメー夕算定を行った交差点遅れ

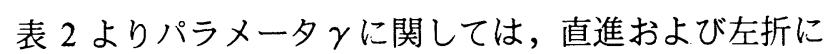
ついては小さな值，右折については比較的大きな值にな っていることがわかる，rの值が小さい直進と左折は, 交差点遅れを小さくする要因の影響が大きいことを示し ている. 右折については信号が青であっても対向直進車 があるため, 交差点遅れを小さくする要因の影響が小さ いことがわかる，一方，パラメータßについては直進に ついては小さく，左折および右折については大きくなっ ている。したがって, 左折および右折車の交差点遅れを 大きくする要因の影響は同じ程度に大きいといえる.

表 3. 交差点遅れの計濉 (積雪路面)

\begin{tabular}{|l|r|r|r|}
\hline & \multicolumn{1}{|c|}{ 直 進 } & \multicolumn{1}{c|}{ 左 折 } & \multicolumn{1}{c|}{ 右 折 } \\
\hline デー夕数 & 115 & 29 & 28 \\
\hline 平均 (秒) & 53.97 & 57.00 & 75.60 \\
\hline 標準偏差 & 25.36 & 28.02 & 40.64 \\
\hline 最大值 & 100.92 & 111.76 & 164.92 \\
\hline 最小值 & 8.92 & 14.76 & 25.92 \\
\hline 平均交差点遅れ & 27.90 & 23.60 & 21.50 \\
\hline 交通量 (台/時) & 534 & 178 & 67 \\
\hline 対向車 (台/時) & & & 504 \\
\hline
\end{tabular}


表 3 は 1998 年 12 月 22 日に積雪路面で計測した交差 点遅れとその統計量を示している. 計測した場所と時間 帯は, 乾燥路面での計測と同様である. 道路の有効幅員 は, 乾燥路面では片側 3 車線であったのに対し, 積雪路 面では堆雪のため片側約 2 車線となっていた。 そのため, 交差点遅れの平均值が乾燥路面と比べ大きくなっている ことがわかる。

表 4 に交差点遅れの計測值より算定された, パラメー 値を示す。

表 4. 交差点遅れのパラメー夕值 (積雪路面)

\begin{tabular}{|l|r|r|r|}
\hline & 直 進 & \multicolumn{1}{c|}{ 左 折 } & \multicolumn{1}{|c|}{ 右 折 } \\
\hline パラメータ : $\gamma^{*}$ & 0.56 & 0.74 & 0.99 \\
\hline パラメータ : $\beta^{*}$ & 44.46 & 131.19 & 105.80 \\
\hline
\end{tabular}

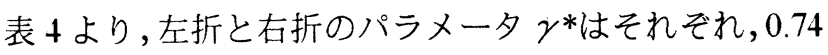
と 0.99 であり, 左折の方が交差点遅れを小さくする要因 の影響が大きいことがわかる。一方，左折と右折のパラ メータ $\beta^{*}$ は, それぞれ 131 と 106 であり, 左折の方が 交差点遅れを大きくする要因の影響が大きいことがわか る. 左折のパラメータ $\beta *$ *右折と異なり, 流入交通量 のみで決定されるため, 右折のパラメータ $\beta^{*}$ よりも大 きくなったと考えられる。

表 2 と表 4 より, 乾燥路面と積雪路面の道路特性が大 きく異なっていることが推測できる.

パラメー夕值の推定に当たっては, 乾燥路面, 積雪路 面とも通過性指数の設定值は表 5 に示す值を用いた.

\section{表 5. 通過性指数の設定值}

\begin{tabular}{|c|c|c|}
\hline 設定値 & $k$ & $\alpha$ \\
\hline 值 & 0.9 & 1.2 \\
\hline
\end{tabular}

\section{(2)交差点遅れ推定モテルの検証}

交差点遅れ関数の代表的なものに, Webster の式が挙 げられる. Webster の式では, 流入交通量が飽和状態で 交差点遅れが無限大になるため, より現実的な式への拡 張が試みられてきた。その理由は，現実には交通流が過 飽和となる時間は有限であり, したがって, 飽和状態に なったとしても交差点遅れは無限大にはならない ${ }^{11}$ から である。これに対し，Webster の式は飽和状態が無限に 続くとして定式化していることになる.

拡張式の代表的なものが Akcelik の式である ${ }^{12)}$. Akcelik の式では過飽和状態での継続時間も考慮して定式化がな されている.ここでは，本交差点遅れ推計モデルの検証 を行うため, 交差点遅れの代表的な式との比較検証を行 った (図7).

図 7 の一様到着の式とは, 式 4 で表されるファジィ交 差点遅れの中心值である.O.D.(Overflow Delay)モデルは， 過飽和状態の交差点遅れの平均值である ${ }^{11}$. Akcelik と O.D.モデルの式はそれぞれ，式 14 と式 15 で表される.
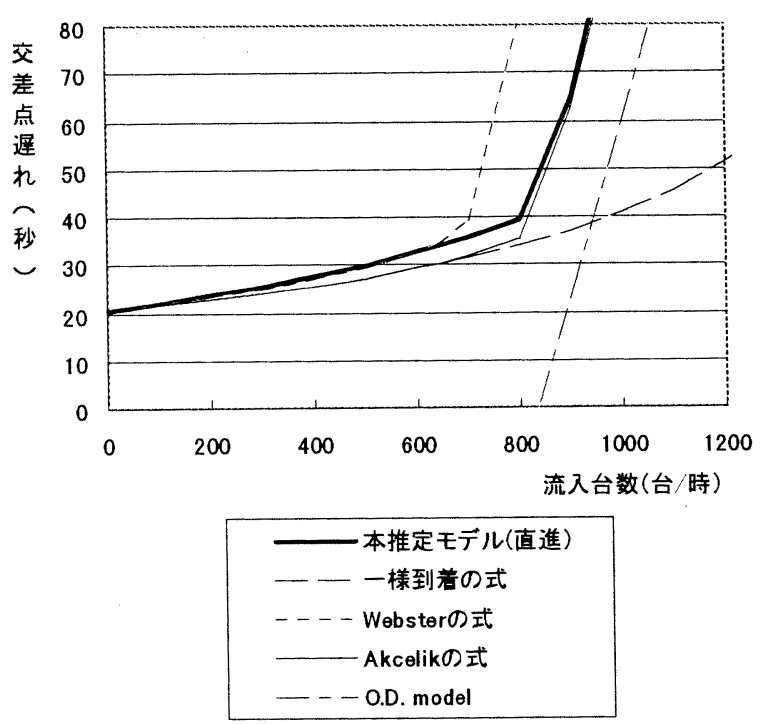

困 7. 各種交差点荤九との比較

$$
\begin{gathered}
d=\frac{0.5 C(1-e)^{2}}{1-e\left(q / C_{I}\right)}+900\left\{q / C_{I}-1+\sqrt{\left(q / C_{I}-1\right)^{2}+\frac{8\left(q / C_{I}-05\right)}{C_{I} T}}\right\} \\
d=(T / 2)\left(q / C_{I}-1\right), \quad q \geq C_{I}
\end{gathered}
$$

ここで， $T$ は交通流の過飽和な状態が続く時間であり， 10 分として設定している. 飽和交通流率，信号のサイ クル時間および青時間比をそれぞれ，2000 (台/時)，110 (秒), 0.4 としている.

流入交通量が過飽和における交差点遅れも適切に表現 する関数の条件は, 流入交通量が飽和未満では Webster の式に近い值をとり，過飽和では Webster の式と O.D.モ デルに挟まれた領域を通ることである ${ }^{11)}$. Akcelik の式 はこの条件を満たしており,こうした交差点遅れ関数の 基準になり得るものである.

図 7 における本モデルによる交差点遅れは, 乾燥路面 における直進車のものを示しており, パラメー夕值は表 2 に示した值, 通過性指数の設定值は表 5 に示した值を 用いている. 本モデルによる交差点遅れは，パラメータ 值を適切に設定することで, (1)流入交通量が飽和未満で は Webster の式と近い值をとり，(2)交差点遅れ計測を実 施した交通量では, 計測值の平均值と一致し, (3)過飽和 状態においても Akcelik の式に近い值をとるという 3 点 から, 交差点遅れが適切に表現されていると考えられる。

積雪路面における交差点遅れは，堆雪による有効幅員 の減少や路面摩擦係数の低下があるため, 厳密な Webster の式や Akcelik の式を表現できない. しかし, 積雪路面 における交差点遅れ計測值よりパラメータ值を設定する ことによって，交差点遅れ計測を実施した交通量では， 本モデルによる交差点遅れと計測值の平均值が一致する ことは保証されている。したがって，積雪路面での交差 点遅れも適切に再現されていると考えられるが, 他の信 号交差点でも計測を行う必要がある. 


\section{4. 交差点遅れを考慮した最短経路探索法}

リンクコストがクリスプ数で, 交差点コストがファジ イ数で表現される経路コストを考える.このとき, 拡張 原理により，その和としての経路コストをファジィ数と して表現可能となる ${ }^{3)}$. さらに, 経路コストの代表值を 重心值とすることによりクリスプな最短経路探索が可能 となる. 最短経路探索は本研究で用いる利用者均衡配分 を計算するために必要なアルゴリズムである（図 8).

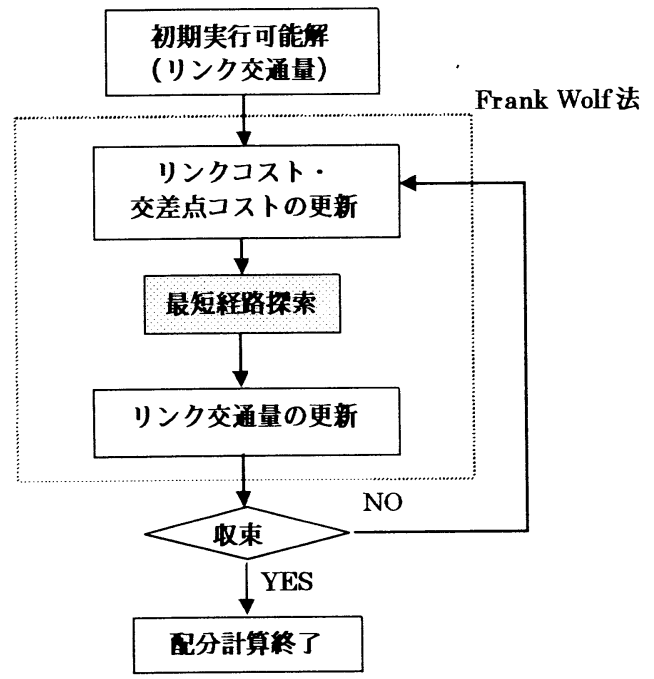

龱 8. 政分計算のフロー

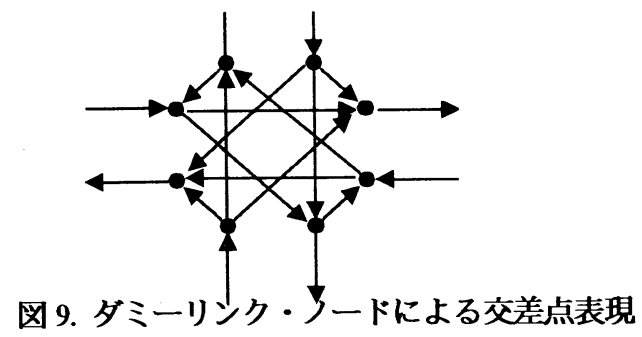

交通量配分における交差点の詳細表現は，(ノード数 8，リンク数 16 の）ダミーノード，ダミーリンクを用い るのが一般的である ${ }^{13)}$ (図 9).しかし同表現法では， ネットワーク表現が煩雑なため計算効率性が良くない.

そのため，本研究ではぺナルティ関数を用いた最短経 路探索アルゴリズム ${ }^{14)}$ を用いる。同アルゴリズムでは交 差点を 1 つのノードとして表現可能である.したがって， 交差点遅れを考慮した最小コスト経路を効率的に求める ことができる。

以下にアルゴリズムを示すが，その前に前提条件とし ていくつかの説明を加える.

ネットワーク $G$ を $G=(V, A)$ と表現する.ここで， $V$ ， $A$ はそれぞれネットワークを構成するノードとリンクの

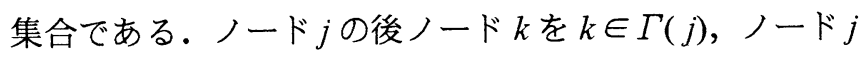
の前ノード $i$ を $i \in \Gamma^{-1}(j)$ と表現する.ノード $i$ を通過し てノード $j$ に到着し, さらにノード $k$ に向かうときの動 き（直進, 左折, 右折に対応）を $m_{k}$ とし, そこまでの 最小経路コスト $\lambda_{j, m k}$ を式 16 で表す.

$$
\begin{aligned}
\lambda_{j, m_{k}}= & \min _{\forall i \in \Gamma^{-1}(j)}\left\{\xi\left(i, j, m_{k}\right)+\tau(i, j)+\lambda_{i, m_{j}}\right\}, \\
& \forall j \in V \text { and } k \in \Gamma(j) \\
\lambda_{j, m_{k}}= & 0, \quad \forall k \in \Gamma(r)
\end{aligned}
$$

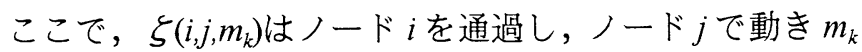
をするときの交差点コスト (交差点遅れ) であり， $\tau(i, j)$ はリンク $(i, j)$ のコトである (図 10). 出発ノードを $r$ としたときの経路 $\pi_{j, m k}$ を式 17 で表す。

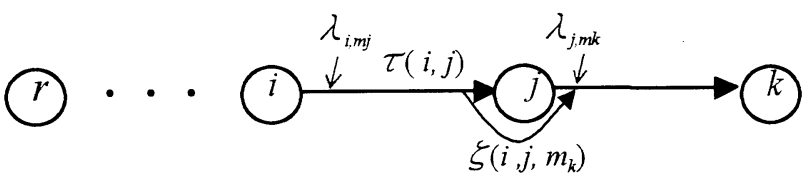

図 10. 経路コストの表現

$$
\pi_{j, m_{k}}=\left\{\left(r, m_{m_{2}}\right),\left(n_{2}, m_{n_{3}}\right) \cdots\left(n_{k-1}=i, m_{j}\right)\left(n_{k}=j, m_{k}\right)\right\}
$$

\section{アルゴリズム}

ステップ 0. 走査可能リスト(Scan Eligible List)に出発ノ 一ド $r$ を挿入し，初期化する.さらに，ラベルを式 18 のように初期化する.

$$
\begin{array}{ll}
\lambda_{i, m_{j}}=\infty, & \forall i \in V \text { and } j \in \Gamma(i) \\
\lambda_{r, m_{k}}=0, & \forall k \in \Gamma(r)
\end{array}
$$

ステップ 1. 走査可能リストが空ならステップ 3 ヘ. そ うでなければ，走査可能リストから最初のノード（ノー ド $i$ とし，これを現在ノードと呼ぶ）を選択し，これを 走查可能リストから削除してステップ 2 ヘ.

ステップ 2a. すべてのノード $j(j \in \Gamma(i))$ が既に走査され ていたなら，ステップ1へ。そうでなければ，走査され ていないノード $j$ を選択し, 式 19 に従い現在ノードを 走查する.

$$
\begin{gathered}
\lambda_{j, m_{k}}=\min \left\{\lambda_{i, m_{k}}, \xi\left(i, j, m_{k}\right)+\tau(i, j)+\lambda_{i, m_{j}}\right\}, \\
\forall \mathrm{j} \in \mathrm{V} \text { and } \mathrm{k} \in \Gamma(\mathrm{j})
\end{gathered}
$$

$\lambda_{j, m k}$ の值が改善された（小さくなった）なら,ノード $i$ と動き $m_{k}$ をそれぞれ前ノード，前動きとして記憶する. 改善されないときは，何もせずに次の動き $m_{k}$ について 続ける。

ステップ $\mathbf{2 b .}$ ノード $j$ での動き $m_{k}$ の代わりに，ノード $j$ にとどまる動きを $|\Gamma(j)|+1$ とし, 式 19 に従い走査する. $\lambda_{j,|\Gamma(j)|+1}$ の值が改善されたなら,ノード $i$ と動き $|\Gamma(j)|+1$ をそれぞれ前ノード，前動きとして記憶する．改善され ないときは，何もせずにステップ $2 \mathrm{c} へ$.

ステップ 2c. すべてのラベル $\lambda_{j, m k}$ の值が改善されたなら， 走査可能リストにノード $j$ を挿入し，ステップ 1 ヘ. ステップ 3. アルゴリズムを終了する.ノード $j$ への最 小経路コストはラベル $\lambda_{j|\Gamma(j)|+1}$ に記憶されており，前ノ 一ドを探すことで経路は確定される。 
同アルゴリズムで最短経路探索を行うときには，本交 差点遅れ推計モデルによる交差点遅れが進行方向（直進, 左折，右折）によって異なるため，それらを区別しなけ ればならない。筆者らは，3つのノードにおける接続関 係に着目し，交差点での進行方向を区別する接続関係行 列を考案している ${ }^{9)}$. 接続関係行列を用いることで，交 差点での進行方向が区別され, 交差点遅れを考慮した最 短経路探索を行うことが可能となる。また，同アルゴリ ズムと接続関係行列とを組み合わせることで，（交差す る道路の一方通行規制に起因しない, 右・左折禁止とい った）複雑な交通規制も表現可能となる.

\section{5. 交差点遅れの利用者均衡配分への適用}

\section{(1)収束条件}

リンクコストが BPR 関数で表現される容量制限付き （確定的）利用者均衡配分に, 交差点遅れ推計モデルを 導入することにする。一般的な利用者均衡配分は, 最適 化問題として定式化される.

本モデルにおける右折車の交差点遅れ $d_{R}$ は, 式 3 お よび式 9 の関係より式 20 で表現される.

$$
d_{R}=d\left(q_{R}, q^{O P}{ }^{\prime}\right)
$$

ここで, $d$ は交差点遅れ関数である. 右折車の交差点遅 れは 2 変数で記述されるため, リンク間に相互干渉のあ る問題となる.こうした利用者均衡配分を最適化問題と して解くための条件は, リンクコスト関数のヤコビアン 行列が対称行列であることである ${ }^{15}$ が，本研究での交通 量配分モデルはこの条件を満たさない，こうした均衡問 題を最適化問題として解くことは，一般的には困難であ り, 複数の均衡解が存在する.

Meneguzzer")は，同様な交通量配分モデルを構筑した。 同モデルでは近似的収束条件を設定しており，その条件 下でのリンク交通量は安定しており, 初期実行可能解に 関わらず相応な均衡状態のリンク交通量パターンが再現 されている。

本研究でも Meneguzzer の近似的収束条件をを用いる ことで近似解を求めることにする。この条件は, 式 21 , 式 22 で表される。

1)リンク収束条件

$$
\left|f_{l}^{n+1}-f_{l}^{n}\right| \leq 0.1 f_{l}^{n}
$$

2)収束計算の終了条件

$$
N_{C} \geq 0.95 L
$$

ここで, $f_{l}^{n}, N_{C}, L$ はそれぞれ Frank Wolf 解法 ${ }^{15)}$ による 収束計算での $n$ 回目におけるリンク $l$ の交通量, 収束し たリンク数, ネットワークの全リンク数である.

収束計算では式 20 において, 関数 $d$ が $q^{O P}{ }^{O}$,を定数と して変数 $q_{R}$ のみの関数で近似できると想定する．この ことによって, リンク間に相互干渉のないコスト関数下
での利用者均衡問題とみなすことが可能となり, FrankWolf 法で収束計算を行うことができる（緩和法） ${ }^{15)}$.

\section{(2)配分計算}

札幌都心部を対象として配分計算を行った。配分対象 ネットワークは, 137 個のノード (そのうち交通が発生・ 集中する 23 個のセントロイド）と，404 本のリンクか ら構成される（図 11）。

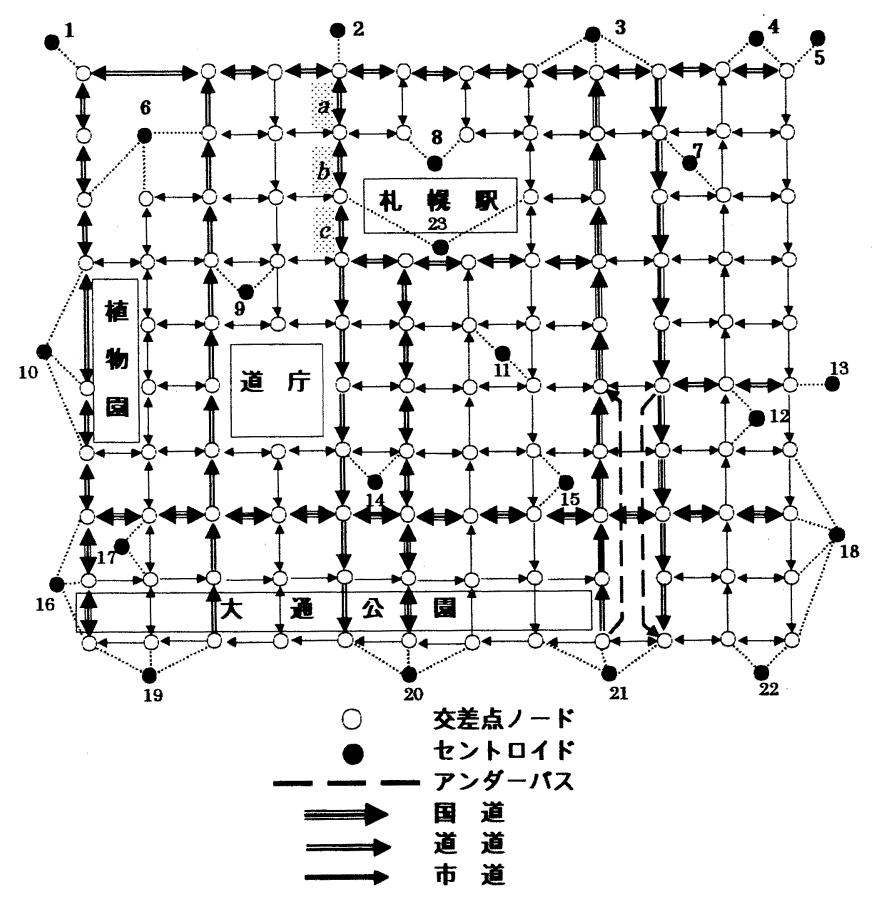

図11. 配分対象ネットワーク

一方通行や右・左折折禁止といった交通規制は, 現行 のものとした。札幌都心部には, 平面部にウィービング 区間のあるアンダーパスが存在するため, 複雑な交通規 制を表現する必要があった。

解析方法は，配分対象ネットワークにおける OD 交通 量も同時に推定可能な 2 段階配分を ${ }^{10 を}$ 適用した。配分 対象ネットワークの OD 交通量推定には，札幌市中ゾー ン問 OD 交通表 ${ }^{17}$ を用いた.配分対象ネットワークの OD 交通量は，交差点遅れを考慮する必要があるため，ピー ク率を $10 \%$ として時間交通量に換算したものを用いてい る(表 6).

交差点遅れを考慮しないとき，すなわち通常の利用者 均衡配分と，交差点遅れを考慮したときの配分交通量の 変化を調べてみた，交差点遅れを考慮したときは，乾燥 路面と積雪路面の場合の 2 通りであり，それぞれ表 2 と 表 4 で示したパラメータ值を全交差点で表現している. 全ての交差点に同じパラメータ值を適用するのは適切な 方法ではないが，平均值といえる札幌市の代表的な信号 交差点でのパラメータ值を用いており，さらに各信号交 差点の交通容量を実際の車線数より算定しているため, 概ね妥当な配分結果を得られることが期待される.ここ での配分計算は, 全ての交差点におけるパラメータ值が 
表 6. OD表（台㭙）

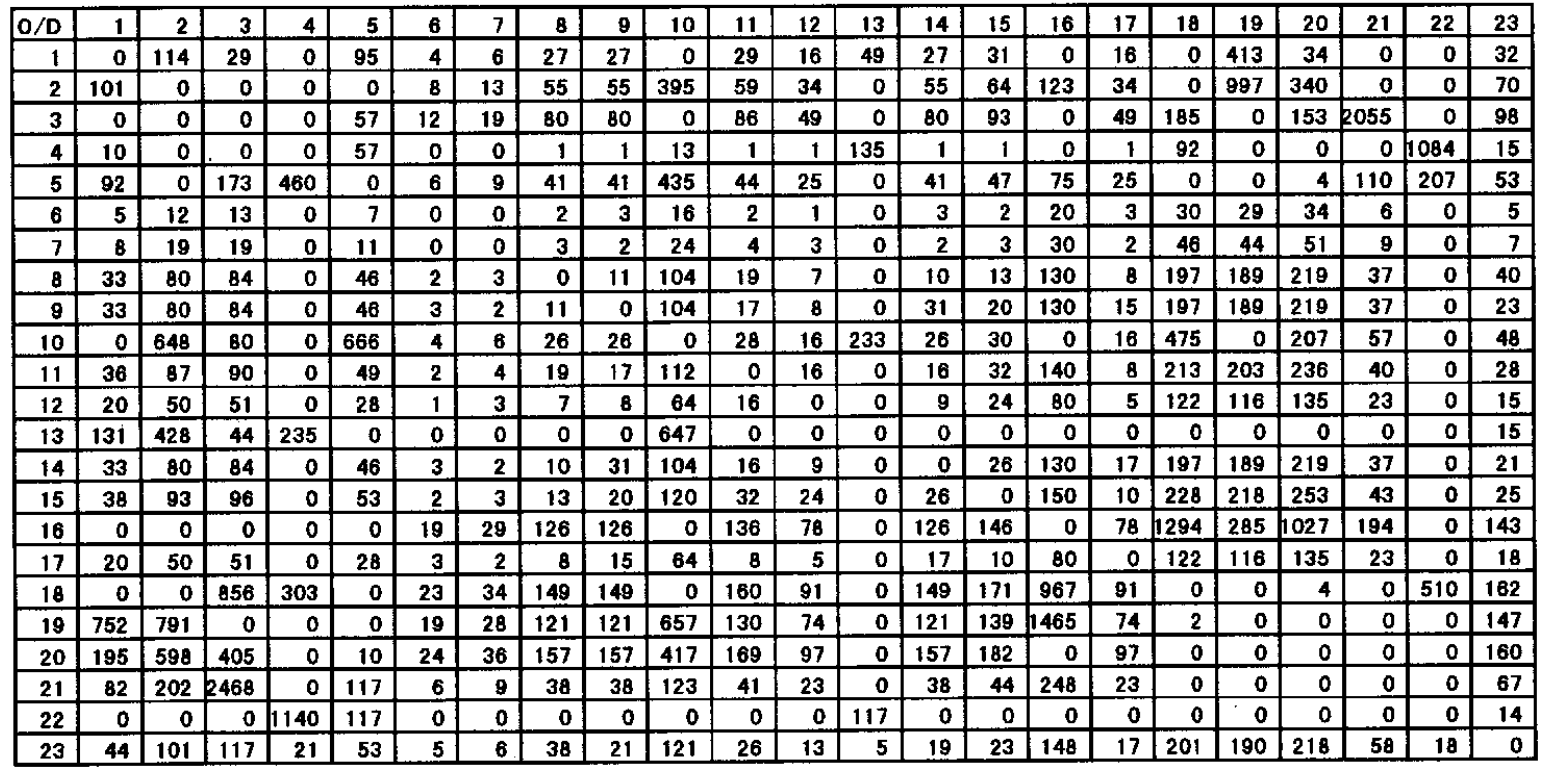

適切に設定されたときに近い結果が得られると仮定して 行っている．しかし，精度を上げることを考えると，国 道, 道道, 市道に分類した 3 種類のパラメータ值を用い ることが現実的であるが，今回は全て同じパラメー夕值 を使用した。また，ITS 技術である路車間通信機能と車 両感知器機能 ${ }^{18)}$ を活用することによって，将来的には必 要な信号交差点におけるパラメー夕値の自動測定が可能 となると考えられる。

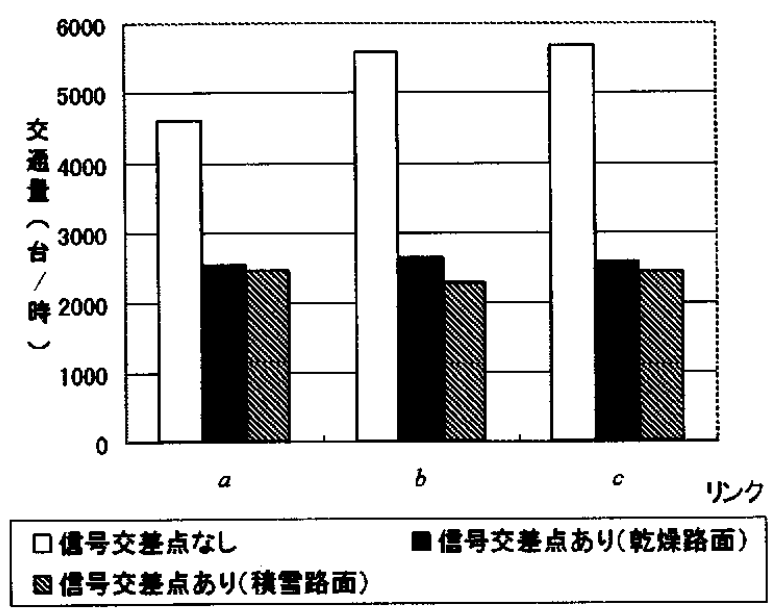

図 12.リンク交通量

図 12 は, 図 11 で示したネットヷークにおけるリンク $a \sim c$ の配分交通量を示している.「信号交差点なし」と は，交差点遅れを考慮しないときの配分交通量であり，

「信号交差点あり」は交差点遅れを考虑したときの配分 交通量である.リンク $a \sim c$ を選択した理由は, 実測交 通量との比較ができることや, 本モデルと通常の利用者 均衡配分による配分交通量の特性が顕著に現れているこ とが挙げられる。

交差点遅れを考慮しない場合と，交差点遅れを考慮し た場合（乾燥路面）との配分交通量を比較すると，数干 台の違いがある.たとえば，リンク $b$ ではそれそれ 5,595
台，2,286 台であり，交差点遅れを考慮しない場合にお いて 3,309 台多くなっている. OD 交通量が時間交通量 であるため，大きな変化であるといえる．この他にも交 差点遅れを考慮した場合と, 考慮しない場合で配分交通 量が大きく異なるリンクが多数存在した．これは交差点 遅れを考虑しないとき，ネットワークでの混雑が表現さ れにくいため, 利用されるリンクと利用されないリンク における配分交通量の差が大きくなったためと考えられ る.すなわち，リンク $a \sim c$ は交差点遅れを考虑しない ときに多く利用されるリンクといえる。一方，交差点遅 れを考虑した場合は,リンク $a \sim c に$ に混雑が生じるため, 交差点遅れを考虑しない場合と比較して，他のリンクヘ 迁回する交通が多くなったといえる．札幌都心部はネッ トワークがグリッド状で，各交差点に信号が設置されて いる特殊な道路構造であるが，他の都市部における配分 計算でも同様な結果が得られると考えられる。

リンク $a$ とリンク $b$ における実測の日交通量 ${ }^{19}$ はそれ ぞれ，30,437 台/日，25,606 台/日である．OD 交通量の設 定と同様にピーク率を $10 \%$ として時間交通量に換算し, 配分交通量と比較したものを表 7 に示す。

表 7. 実瞋との此校 (単位 : 台㭙)

\begin{tabular}{|c|r|r|}
\hline & リンク $a$ & リンク $b$ \\
\hline 実測值 & 3044 & 2561 \\
\hline 信号交差点あり (乾燥路面) & 2536 & 2643 \\
\hline 信昂交差点あり (積雪路面) & 2457 & 2536 \\
\hline 遲れなし & 4594 & 5595 \\
\hline
\end{tabular}

表 7 より交差点遅れを考慮したときの方が実測值に近い 值をとることがわかる。

交差点遅れを考虑したとき, 乾燥路面と積雪路面での 配分交通量の違いは, 積雪路面のときリンク $a \sim c$ の配 分交通量が乾燥路面より少ないことである。たとえばリ ンク $b$ は, 乾燥路面では 2643 台, 積雪路面では 2536 台 
であり, 積雪路面において 107 台少なくなっている.こ れは，乾燥路面と比較すると，積雪路面での混雑が大き いため，一部の交通が迁回して他のリンクに流れたため である。ネットワーク全体でみると, 乾燥路面で（交通 容量に対して）大きかったリンク交通量が積雪路面では 減少し, 逆に乾燥路面で小さかったリンク交通量が積雪 路面では增加しているという傾向があった。

表 8 に，交差点遅れを考慮したときの（乾燥路面と積 雪路面）ネットワーク全体での総走行時間を示す．乾燥 路面と積雪路面における総走行時間を比較すると, 積雪 路面での総走行時間は, 乾燥路面の 3 倍以上となること がわかる. 積雪路面の総走行時間は, 乾燥路面において OD 交通量を $16 \%$ （約 7,000 台/時）增加させた時間に相 当する，積雪路面の総走行時間の増大は，交差点遅れの 増大によるものであり, 積雪寒冷地の冬期における交通 渋滞原因の 1 つであると推察される.

\section{表 8. 総走行時間の比較}

\begin{tabular}{|c|c|c|}
\hline & 乾燥路面 & 積雪路面 \\
\hline 総走行時間 (台·秒) & $84,700,000$ & $304,000,000$ \\
\hline
\end{tabular}

\section{(3)交通量配分法の特長}

本交通量配分法の特長は，第 1 に，近似的均衡条件を 設定することにより，リンク間に相互干渉のある交差点 遅れ関数を利用者均衡配分に適用したことである.この ことにより，交差点における自動車の挙動を考える上で 無視できない，右折車に対する対向直進車の影響を考慮 することが可能となる.

第 2 に, 交差点遅れが飽和交通流率や交通の到着分布 によって変動するため，こうした要因に対する調整プロ セスを有する交差点遅れ推計モデルを導入したことであ る. 交差点遅れ関数は, 交差点遅れの計測を行うことに よりパラメー夕值の設定を行っているため, 配分計算に おいても妥当な交差点遅れが再現されると考えられる.

第 3 に, 交差点遅れを考慮することにより, 混雑が表 現されるため, それに伴う迂回交通を表現できることで ある. 交差点遅れを考慮しない利用者均衡配分では, 配 分交通量が 0 となるリンクはあまり存在しないが, 利用 されるリンクと, 利用されないリンクにおける交通量の 差は大きい。これは, 混雑による迁回交通が適切に表現 されていないためである.

第 4 に, ファジィ交差点遅れ推計に必要なパラメータ 值を測定するため, 積雪路面を仮定した配分計算も行う ことができることである，さらに，総走行時間を計算す ることにより, 乾燥路面と積雪路面の影響を計量的に把 握することができる。

第 5 に, 交差点遅れを考慮して，かつ効率的に最短経 路探索が可能なアルゴリズムを適用したことである。こ のことにより, 図 9 に示したような煩雑な交差点の詳細 表現を行う必要がなくなる.さらに，同アルゴリズムと
接続関係行列とを組み合わせることで, 複雑な交通規制 も表現可能となる。

\section{6. おわりに}

本研究では, 交通量配分に適用可能な交差点遅れ推計 モデルを構筑し，同モデルを利用者均衡配分に導入した 交通流解析法を提案した。同解析法を都市部に適用する と, 従来の利用者均衡配分より混雑を適切に表現でき, その結果, 妥当な結果を得られることを示した.さらに， 乾燥路面と積雪路面におけるモデルパラメータ值を測定 することにより，それぞれの配分交通量および総走行時 間の違いを計量的に把握できることを示した。

信号制御は，都市部における交通流を制御可能な，有 用かつ柔軟性のある唯一の方法といえる.したがって, 信号制御変数 (青時間比等) の最適化を行うこと ${ }^{20)}$ は, 重要な課題である。本解析法では, 交差点遅れ関数に信 号制御変数は記述されているが，その最適化は行ってい ない.これは, 今後の課題としたい。

\section{参考文献}

1）赤松隆他 : 時間帯別 $\mathrm{OD}$ 需要と渋滞を内生化した準動 的交通配分, 土木計画学研究論文集, No15, pp535 545, 1998

2） 藤田素弘他: 時間帯別交通量配分モデルの開発と実用 化に関する研究，土木学会論文集，No389，pp111～119, 1988

3）秋山孝正：ファジィ経路情報に基づくネットワーク解 析, 土木学会論文集, No449/IV-17, pp.145〜154, 1992

4) CLAUDIO MENEGUZZER : AN EQUILIBRIUM ROUTE CHOICE MODEL WITH EXIPLICIT TREATMENT OF THE EFFECT OF INTERSECTIONS,

TRANSPORTATION RESERCH Vol. 29B, No. 5, PP329 356, 1995

5) DAVID WALTING: ASYMMETRIC PROBLEMS STOCHASTIC PROCESS MODELS OF TRAFFIC ASSIGNMENT, TRANSPORTATION RESERCH, Vol. 30, No. 5, PP339 357, 1996

6）交通工学研究会編：平面交差点の計画と設計一応用編 一, 交通工学研究会, 1983

7）鹿田成則他：信号交差点における飽和交通流率の変動の 基本特性, 土木計画学研究・論文集, No.14, pp.877 882, 1997.

8) Ken-etsu UCHIDA, Shin-ei TAKANO, Seiichi KAGAYA and Keiichi SATOH: ESTIMATION OF THE ASSIGNED TRAFFIC VOLUME IN CONSIDERATION OF SIGNALIZED INTERSECTIONS, Journal of the Eastern Asia Society for Transportation Studies, Vol2, No3, pp777 793, 1997

9）内田賢悦, 岸邦宏, 佐藤馨一 :メンバーシップ関数を 用いた交差点遅れ推計モデルの構筑, 土木計画学研 究・講演集, No21(1)，pp439 442，1998

10）交通工学研究会編：交通工学ハンドブック，技報堂出 版, pp156 158, 1984

11) V.F.HURDLE: Signalized Intersection Delay Models $-A$ Primer for the Uninitiated, TRANSPORTATION RESERCH RECORD, No971, pp. 96 104, 1984

12) Akcelik R: The Highway Capacity Manual delay formula for 
signalized intersections, ITE J, 58(3), 23〜27, 1988

13）森津秀夫：交通ネットワーク表現と最短経路探索法, 交通工学, Vol.25, No6, pp21〜31, 1990

14) ATHANASIOS K. ZILIASKOPOULOS, HANI S.MAHMASSANI: A NOTE ON LEAST TIME PATH COMPUTATION CONSIDERING DELAYS AND PROHIBITIONS FOR INTERSECTION MOVEMENT, TRANSPORTATION RESERCH 30B, PP359〜367, 1996

15）土木学会: 交通ネットワークの均衡分析 一最新の理 論と解法一, 1998

16）朝倉康夫他：2 段階配分と OD 推計を組み合わせた道 路網交通流分析手法の適用, 第 17 回交通工学研究発 表会論文報告集，pp185〜188，1997

17）札幌市：2015 年マスタープラン中ゾーン間自動車 OD 表, 1996

18）桑原雅夫：ITS への期待，交通工学，Vol33，pp19〜25, 1998

19）札幌市企画調整局総合交通計画部：平成 8 年交通量調 査集計結果表，1997

20) M. J. SMITH and T. VAN VUREN: Traffic Equilibrium with Responsive Traffic Control, Transportation Science, Vol. 72, No. 2, ppl18〜132, 1993

\section{交差点遅れを考慮した利用者均衡配分に関する研究}

内田賢悦, 岸邦宏, 佐藤馨一

交差点遅れは飽和交通流率や交通の到着分布によって変動するため, その推定にはこうした要因に対す る調整プロセスが必要である。本研究では, 飽和交通流率や交通の到着分布に対する調整プロセスを有 するメンバーシップ関数による交差点遅れ推計モデルを構筑した. 同モデルでは, 交差点遅れ推計に必 要なパラメータ值を交差点遅れ計測により測定している. 本推定モデルを交通量配分に適用すると妥当 な交差点遅れが再現され，また混雑による迁回交通の影響が配分交通量に反映されるようになった。本 研究は，同交差点遅れ推計モデルを利用者均衡配分に導入した，交通流解析法を提案するものである.

\section{A Study on User Equilibrium Assignment considering Intersection Delays}

By Ken-etsu UCHIDA, Kunihiro KISHI and Keiichi SATO

Since intersection delays varies with saturation flow rate and arrival distribution of vehicles, estimating intersection delay needs adjustment process which works these factors. We developed a model which estimates intersection delays using membership function with adjustment process of saturation flow rate and arrival distribution of vehicles. Since parameters in the model are set by measuring intersection delays, the intersection delays from the model have a conformity with real ones performing the traffic assignment. In this study, we propose a traffic analysis method which introduces the estimation model of intersection delays to user equilibrium assignment. 